\title{
PENGARUH KINERJA KEUANGAN TERHADAP SISTEM INFORMASI AKUNTANSI (SIA) PADA USAHA KECIL MENENGAH (UKM) DI BANDAR LAMPUNG
}

\author{
Meita Sekar Sari \\ Universitas Mitra Indonesia, Program Studi Akuntansi \\ Email.Meita@umitra.ac.id \\ Sugiyani \\ Universitas Mitra Indonesia, Program Studi Akuntansi \\ Email.gieyasandi13@gmail.com
}

\begin{abstract}
"BPS-Statistics Indonesia, 2017: 23" State: economic development in Indonesia Small and Medium Enterprises (SMEs) are always described as a sector that has an important role. Described in Kompas. Com many Small and Medium Enterprises (SMEs) are developing at this time, that there are still a lot of Small and Medium Enterprises (SMEs) actors who do not realize the importance of neat financial records and bookekeeping, most of the Small and Medium Enterprises (SMEs) actors are still" blind "accounting. As a result, it is natural that many of them do not have a bookekeeping business that has the potential to grow. This type of research is quantitative with a collaborative research design. The population in this study are all small and medium businesses in Bandar Lampung, which have been recorded at the Central Statistics Agency (BPS) of Lampung province, amounting to 278 SMEs. Respondents obtained and used in this study were 55 SMEs. Analysis of the data used in this study is the classic assumption test and multiple regression analysis using the simultaneous test (Fcount test) and persial test (t test). The results showed that the output results can be seen that the calculated $F$ value of 5,020, when compared with the value of the table $f$ of 2.40, then F count $>$ F table then the Cash Ratio, Current Ratio, Return On Assets, Return On Equity, and Net Profit Margin together with the accounting information system is accepted, HO is rejected. T Test results show that Cash Ratio, Current Ratio, Return On Equity (ROE), and Net Profit Margin significantly influence the Accounting Information System (AIS), while Return On Assets do not significantly influence the Accounting Information System (SIA). The results of multiple linear regression analysis showed the coefficient of determination ( $\mathrm{R}$ Square) of 0.705 or $70.50 \%$ which means that changes that occur in the accounting information system (SLA) (Y) can be explained by the variable Cash Ratio, Current Ratio, ROA, ROE, and NPM (X1, X2, X3, X4, and $X 5)$ of $70.50 \%$, and the remaining $29.50 \%$ is explained by other variables not proposed in this study.
\end{abstract}

Keywords : Financial Performance, Ratio Analysis, Accounting Information Systems (AIS) and Small and Medium Enterprises (UKM) 


\section{Abstrak}

"Badan Pusat Statistik, 2017: 23" menyatakan bahwa: pembangunan ekonomi di Indonesia sector Usaha Kecil Menengah (UKM) selalu digambarkan sebagai sektor yang memiliki peran penting. Dijelaskan dalam kompas.com banyak Usaha Kecil dan Menengah (UKM) yang berkembang saat ini, bahwa masih banyak pelaku Usaha Kecil Menengah (UKM) yang tidak menyadari pentingnya catatan keuangan yang rapi dan pembukuan, sebagian besar Pelaku Usaha Kecil dan Menengah (UKM) masih "buta" akuntansi. Akibatnya, wajar bahwa banyak dari mereka tidak memiliki bisnis pembukuan yang memiliki potensi untuk tumbuh. Jenis penelitian ini adalah kuantitatif dengan desain penelitian kolaboratif. Populasi dalam penelitian ini adalah semua usaha kecil dan menengah di Bandar Lampung, yang telah dicatat di Badan Pusat Statistik (BPS) Provinsi Lampung, berjumlah 278 UKM. Responden yang diperoleh dan digunakan dalam penelitian ini adalah 55 UKM. Analisis data yang digunakan dalam penelitian ini adalah uji asumsi klasik dan analisis regresi berganda menggunakan uji simultan (uji $F_{\text {hitung}}$ ) dan uji parsial (uji t). Hasil penelitian menunjukkan bahwa hasil keluaran dapat dilihat bahwa nilai $\mathrm{F}$ yang dihitung sebesar 5,020, jika dibandingkan dengan nilai tabel f sebesar 2,40, maka F hitung $>$ F tabel kemudian pada Rasio Kas, Rasio Lancar, Rasio Aktiva Aktif, Return On Asset, Return On Ekuitas, dan Net Profit Margin bersama dengan sistem informasi akuntansi diterima, $\mathrm{H} 0$ ditolak. Hasil Uji T menunjukkan bahwa Cash Ratio, Current Ratio, Return On Equity (ROE), dan Net Profit Margin berpengaruh signifikan terhadap Sistem Informasi Akuntansi (AIS), sedangkan Return On Asset tidak berpengaruh signifikan terhadap Sistem Informasi Akuntansi (SIA). Hasil analisis regresi linier berganda menunjukkan koefisien determinasi (R Square) sebesar 0,705 atau $70,50 \%$ yang berarti bahwa perubahan yang terjadi pada sistem informasi akuntansi (SIA) (Y) dapat dijelaskan oleh variabel Cash Ratio, Current Ratio, ROA, ROE, dan NPM (X1, X2, X3, X4, dan X5) sebesar 70,50\%, dan sisanya $29,50 \%$ dijelaskan oleh variabel lain yang tidak diusulkan dalam penelitian ini.

Kata kunci: Kinerja Keuangan, Analisis Rasio, Sistem Informasi Akuntansi (AIS) dan Usaha Kecil Menengah (UKM) 


\section{Pendahuluan}

"BPS-Statistics Indonesia, 2017:23" menyatakan: pembangunan ekonomi di Indonesia Usaha Kecil Menengah (UKM) selalu digambarkan sebagai sektor yang mempunyai peranan penting, karena pengalaman sejarah menunjukkan Usaha Kecil Menengah (UKM) mampu bertahan terhadap krisis ekonomi yang pernah dialami Indonesia beberapa tahun sebelumnya."KOMPAS.Com, 26 April 2018" Dijelaskan dalam Kompas.Com mengenai fenomena yang banyak diperbincangkan mengenai Usaha Kecil Menengah (UKM) yang berkembang saat ini, bahwa masih banyak sekali pelaku Usaha Kecil Menengah (UKM) yang belum menyadari pentingnya pencatatan keuangan dan pembukuan yang rapi, Bahkan, saat ini sebagian besar pelaku Usaha Kecil Menengah (UKM) masih "buta" akuntansi. Akibatnya, wajar jika banyak diantara mereka tidak memiliki pembukuan bisnisnya yang berpotensi makin membesar.

"Badan Pusat Statistik Profinsi Lampung, 2018:23" Pelaku UKM telah menyumbang Produk Domestik Bruto (PDB) nasional hingga 60\% dan menyerap 97\% tenaga kerja. Berdasarkan survei UKM 2017 tahunan Data Badan Perencanaa Pembangunan Nasional, Badan Pusat Statistik dan United Nation Population Found terdapat 4,46 juta usaha/perusahaan yang tersebar di seluruh wilayah Indonesia, 4,10 juta (91,96\%) diantaranya adalah industri mikro dan sisanya adalah industri kecil. Sedangkan di Kota Bandar Lampung sendiri terdapat 2.125 Usaha Kecil Menengah (UKM) yang terdaftar di Departemen Perdagangan dan Perindutrian (Deperindag) kota Bandar Lampung dan tercatat pada Badan Pusat Statistik Provinsi Lampung. Dari data tersebut terdapat 278 Usaha Kecil Menengah tersebut 48 diantaranya adalah Perusahaan/Usaha Industri Menengah (Sedang) dan sisanya sebanyak 230 adalah Perusahaan/Usaha Industri Kecil.

"CPS.Soft, Cipta Prianti Sejabtera. Oktober:2019” Melihat fenomena yang dijelaskan sebelumnya serta disandingkan dengan fakta yang terjadi dimana peran akuntansi bagaikan denyut nadi dalam bisnis. Arus kas, pengeluaran, pendapatan, laba-rugi dan penganggaran adalah hal yang harus diketahui untuk semua perusahaan, terlepas dari jenis industri atau skala bisnis. Baik itu kepemilikan tunggal, perusahaan multinasional bahkan UKM sekalipun harus tau peran akuntansi bagi finansial bisnis yang dijalankan.

Dengan demikian, dapat dilihat bahwa Informasi Akuntansi dalam prakteknya tidak banyak dilaksanakan. Padahal Sistem Informasi Akuntansi (SIA) memiliki tujuan utama dalam penyusunan laporan keuangan, hal ini disebabkan karena tidak adanya peraturan yang mewajibkan untuk penyusunan laporan keuangan bagi Usaha Kecil Menengah (UKM) itu sendiri.

Berdasarkan latar belakang diatas, maka tujuan dari penelitian ini adalah untuk mengetahui dan menganalisis Pengaruh Kinerja Keuangan Terhadap Sistem Informasi Akuntansi (SIA) Pada Usaha Kecil Menengah (UKM) Di Bandar Lampung. 


\section{Tinjauan Pustaka \\ Kinerja Keuangan}

Kinerja merupakan hasil pekerjaan yang mempunyai hubungan yang kuat dengan tujuan strategis organisasi, kepuasan konsumen dan memberikan kontribusi ekonomi. Kinerja yang efektif dan efisien menjadi tolak ukur keberhasilan suatu perusahaan. "Wibowo, 2016:160" Pengukuran kinerja suatu perusahaa dapat dilakukan dengan berbagai ukuran dan cara. banyak faktor yang dapat dijadikan ukuran kinerja, namun ukuran kinerja harus relevan, signifikan dan komperhensif.

\section{Analisis Rasio Keuangan}

Pengertian rasio keuangan menurut James C Van Horne merupakan indeks yang menghubungkan dua angka akuntansi dan diperoleh dengan membagi satu angka dengan angka lainnya. Rasio keuangan digunakan untuk mengevaluasi kondisi keuangan dan kinerja perusahaan. Dari hasil rasio keuangan ini akan terlihat kondisi kesehatan perusahaan yang bersangkutan.

1. Rasio Kas (Cash Ratio)

"Kasmir, 2014:139" Rasio kas atau cash rasio merupakan alat yang digunakan untuk mengukur seberapa besar uang kas yang tersedia untuk membayar utang. Ketetrsediaan uang kas dapat ditunjukan dari tersedianya dana kas atas yang setara dengan kas seperti rekening giro atau tabungan di bank (yang dapat ditarik setiap saat).

2. Ratio Lancar (Current Ratio)

"Kasmir, 2014:135" merupakan ratio untuk mengukur kemampuan perusahaan dalam membayar kewajiban jangka pendek atau utang yang akan segera jatuh tempo pada saat ditagih secara keseluruhan. "Pahala Nainggolan, 2015:6" Pada Usaha Kecil Menengah (UKM) nilai penting uang kas menjadi lebih besar ketimbang usaha berskala besar lainnya. Karena modal Usaha Kecil Menengah (UKM) terbatas maka hambatan dalam arus kas dapat berakibat fatal. Kas keluar harus singkron dengan kas masuk, baik jumlah maupun waktunya.

\section{Return On Asset (ROA)}

Return On Asset (ROA) merupakan rasio yang digunakan untuk mengukur kemampuan manajemen dalam mengelola modal dan diinvestasikan ke dalam total asset dalam menghasilkan pendapatan. Rasio ini menunjukan berapa besar laba bersih yang diperoleh perusahaan bila diukur dari nilai asset perusahaan.

\section{Return On Equity (ROE)}

"Kasmir, 2014:204" Return On Equity (ROE) ini merupakan rasio yang paling penting dan dihitung dengan cara membandingkan laba bersih setelah pajak dengan ekuitas. Rasio ini menunjukan berapa persen diperoleh laba bersih bila diukur dari modal pemilik.

\section{Net Profit Margin (NPM)}

"Dr.Kasmir, 2014:200" Rasio Net Profit Margin digunakan untuk mengukur seberapa besar kemampuan perusahaan dalam menghasilkan laba 
bersih dari penjualan bersih. Rasio ini mengukur hasil akhir dari kegiatan dari operasi perusahaan.

Analisis rasio digunakan untuk mengukur kinerja keuangan. Rasio keuangan yang digunakan adalah Cash Ratio, Current Ratio, Return On Asset (ROA), Return On Equity (ROE), dan Net Profit Margin (NPM). Penulis hanya memilih rasio ini karena sesuai dengan kebutuhan dari lingkup kegiatan dan pencatatan yang kiranya dilakukan oleh Usah Kecil Menengah (UKM) di Bandar Lampung.

\section{Laporan Keuangan Sebagai Alat Penilaian Kinerja Keuangan}

Dengan memeperoleh laporan keuangan suatu perusahaan, akan dapat diketahui kondisi keuangan perusahaan secara menyeluruh. Kemudian laporan keuangan tidak hanya sekedar cukup dibaca, tetapi juga harus dimengerti dan dipahami tentang posisi keuangan perusahaan saat ini. Caranya adalah dengan melakukan analisis keuangan melalui berbagai rasio keuangan yang lazim dilakukan. Penilaian kinerja keuangan akan menjadi patokan atau ukuran apakah manajemen mampu atau berhasil dalam menjalankan kebijakan yang telah digariskan.

\section{Sistem Informasi Akuntansi (SIA)}

"Dr.Mardi, 2014:4" Dalam buku "Sistem Informasi Akuntansi", menurut Wijayanto (2001) Sistem Informsi Akuntansi adalah susunan berbagai dokumen, alat komunikasi, tenaga pelaksana, dan berbagai laporan yang di desain untuk mentransformasikan data keuangan menjadi informasi keuangan, Dapat disimpulkan, Sistem Informasi Akuntansi dapat diartikan sebagai suatu kegiatan yang terintegrasi yang menghasilkan laporan dibentuk data transaksi bisnis yang diolah dan disajikan sehingga menjadi sebuah laporan keuangan yang memiliki arti bagi pihak yang membutuhkannya.

\section{Usaha Kecil Menengah (UKM)}

Menurut Undang-Undang Nomor 20 Tahun 2008 usaha kecil adalah usaha ekonomi produktif yang berdiri sendiri, yang dilakukan oleh orang perorangan atau badan usaha yang bukan merupakan anak perusahaan atau bukan cabang perusahaan yang dimiliki, dikuasai atau menjadi bagian baik langsung maupun tidak langsung dari usaha menengah dan usaha besar yang memenuhi kriteria usaha kecil. "Badan Pusat Statistik, 2017:03" Secara umum, pembangunan sektor industri pengolahan nasional mencanangkan pembangunan UKM yang berdaya saing dengan struktur yang kuat berbasis sumber daya alam, inovasi dan teknologi serta berkeadilan. Secara umum kontribusi Usaha Kecil Menengah (UKM) terhadap perekonomian Indonesia selama 2010 - 2016 secara rata-rata mencapai 21,27 \%. Khusus Usaha Kecil Menengah (UKM) di tahun 2016 mampu menyerap tenaga kerja sebesar 9,4 juta orang. 


\section{Sistem Informasi Akuntansi dan Proses Pengambilan Keputusan}

Dengan memanfaatkan sistem informasi akuntansi, UKM dapat mengumpulkan informasi lebih akurat untuk pembuatan keputusan, yang akan mengakibatkan meningkatkan tingkat efisiensi organisasi dan juga dapat meningkatkan laba organisasi tersebut. Perren \& Grant (2001) menjelaskan bahwa proses pengambilan keputusan di UKM lebih maju daripada apa yang mereka pikirkan. Mereka menemukan bahwa kurangnya efektivitas informasi akuntansi dan sistem pengawasan untuk mendukung bisnis mereka sering disebabkan oleh pengguna yang tidak memiliki pengetahuan bagaimana menerapkan teknik akuntansi resmi menjadi kenyataan. Namun, studi yang mengadopsi pendekatan yang lebih subjektif dimana UKM yang sebenarnya mengandalkan informasi akuntansi yang memadai, termasuk akuntansi manajerial, yang sering membuat keputusan bisnis mereka melalui caracara informal.

Perren \& Grant (2001) menyimpulkan bahwa temuan sebaliknya didasarkan pada paradigma para peneliti daripada pertentangan nyata. Argumen ini didukung oleh Federasi Internasional Akuntan (IFA 2006), yang melaporkan bahwa kesadaran perusahaan-perusahaan kecil untuk menggunakan SIA untuk berbagai tujuan tergantung pada variasi bisnis. Oleh karena itu, penyelidikan lebih lanjut harus diperhitungkan untuk menentukan tingkat kebutuhan SIA di UKM.

\section{Metode Penelitian \\ Desain Penelitian}

Penelitian ini menggunakan desain penelitian kolerasional, yaitu desain penelitian yang digunakan untuk mengetahui hubungan antara variabel bebas (independen) dan variabel terikat (dependen). Pada penelitian ini variabel bebas (independen) yang digunakan yaitu Kinerja Keuangan yang diukur berdasarkan perhitungan Rasio Keuangan (Cash Ratio, Current Ratio, Return On Asset (ROA), Return On Equity (ROE), dan Net Profit Margin (NPM)). Sedangkan variabel terikat (dependen) yang digunakan adalah Sistem Informasi Akuntansi.

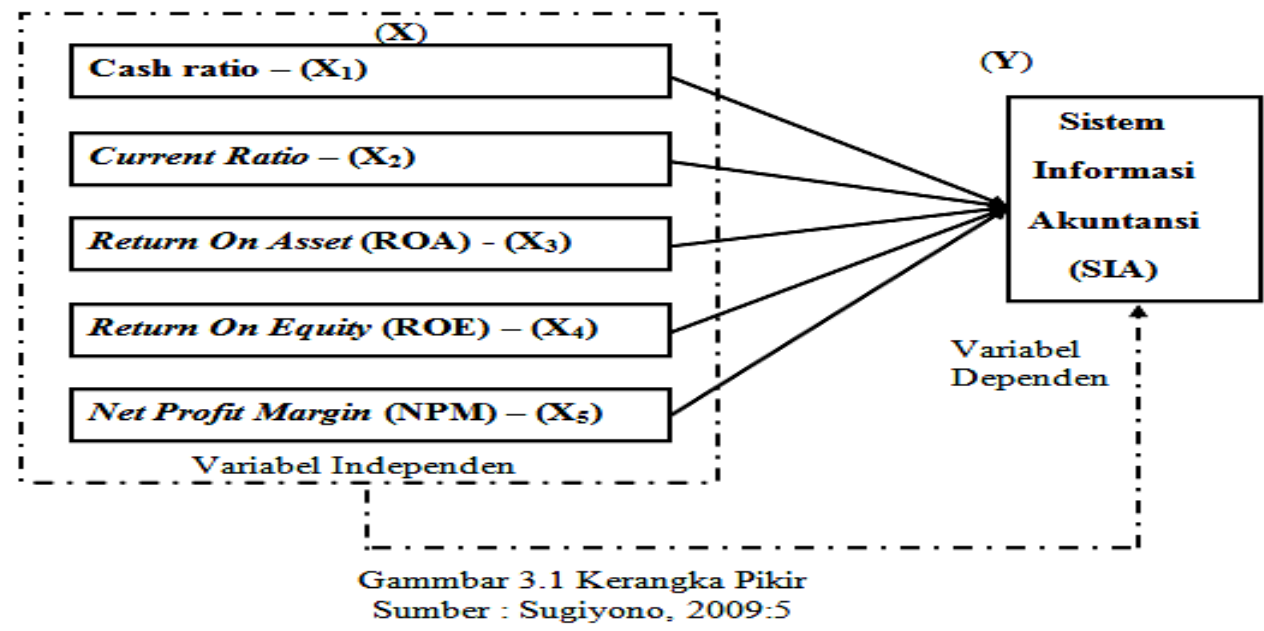


Penelitian ini dilakukan pada Usaha Kecil Menengah (UKM) di Bandar Lampung yang telah terdaftar pada Kamar Dagang dan Industri (KADIN) dan atau Departemen Perdagangan dan Perindustrian (Deperindag) kota Bandar Lampung dan yang tercatat pada Badan Pusat Statistik (BPS) provinsi Lampung tahun 2017. Waktu penelitian ini dilakukan daribulan april sampai dengan penelitian ini selesai.

\section{Populasi dan Sampel Penelitian}

"Chairul Anwar, 2017:29" Menurut Djarwanto dalam buku "Metodologi Penelitian" menjelaskan bahwa, populasi atau universe adalah jumlah keseluruhan dari satuan-satuan atau individu-individu yang karakteristiknya hendak diteliti. Dimana populasi sasaran dalam penelitian ini adalah Usaha Kecil Menengah di Bandar Lampung yang telah tercatat pada Badan Pusat Statistik (BPS) provinsi Lampung berjumlah 278 (Dua Ratus Tujuh Puluh Delapan)UKM.

Tabel 1:

Usaha Kecil Menengah di Bandar Lampung

\begin{tabular}{|l|l|c|c|c|c|}
\hline \multirow{2}{*}{ No } & \multicolumn{1}{|c|}{ Kecamatan } & Besar & Sedang & Kecil & \multirow{2}{*}{ Jumlah } \\
\cline { 3 - 6 } & & $\mathbf{<} \mathbf{1 0 0}$ & $\mathbf{2 0 - 9 9}$ & $\mathbf{5 - 1 9}$ & \\
\hline 1 & Teluk Betung Barat & 1 & 3 & 4 & 8 \\
\hline 2 & Teluk Betung Timur & 1 & 4 & 9 & 15 \\
\hline 3 & Teluk Betung Selatan & 3 & 2 & 8 & 13 \\
\hline 4 & Bumi Waras & 3 & 1 & 8 & 12 \\
\hline 5 & Panjang & 3 & 2 & 18 & 23 \\
\hline 6 & Tanjung Karang Timur & 3 & 3 & 17 & 23 \\
\hline 7 & Kedamaian & 7 & 2 & 22 & 33 \\
\hline 8 & Teluk Betung Utara & 5 & 1 & 9 & 15 \\
\hline 9 & Tanjung Karang Pusat & 6 & 2 & 35 & 45 \\
\hline 10 & Enggal & 7 & 3 & 12 & 22 \\
\hline 11 & Tanjung Karang Barat & 3 & 1 & 10 & 14 \\
\hline 12 & Kemiling & 2 & 5 & 25 & 32 \\
\hline 13 & Langkapura & 3 & 4 & 18 & 25 \\
\hline 14 & Kedaton & 2 & 3 & 24 & 29 \\
\hline 15 & Rajabasa & 3 & 4 & 15 & 22 \\
\hline 16 & Tanjung Senang & 1 & - & 6 & 7 \\
\hline 17 & Labuhan Ratu & 3 & 2 & 13 & 18 \\
\hline 18 & Sukarame & 2 & 1 & 4 & 7 \\
\hline 19 & Sukabumi & 1 & 3 & 17 & 21 \\
\hline 20 & Way Halim & 4 & 2 & 7 & 13 \\
\hline BANDAR LAMPUNG & $\mathbf{7 3}$ & $\mathbf{4 8}$ & $\mathbf{2 3 0}$ & $\mathbf{3 9 9}$ \\
\hline
\end{tabular}

Sumber : Badan Pusat Statistik (BPS) Provinsi Lampung dan Podes Bandar Lampung dalam angka 2018.

"Chairul Anwar, 2017:29" Menurut Djarwanto sampel atau contoh adalah sebagian dari populasi yang karakteristiknya hendak diteliti. Teknik 
pengambilan sampel yang digunakan dalam penelitian ini adalah Teknik Sampling secara Probabilitas/Acak, yang merupakan teknik sampling yang dilakukan dengan memberikan peluang atau kesempatan kepada seluruh anggota populasi untuk menjadi sampel. Selanjutnya dalam penelitian ini teknik sampling yang dilakukan dengan cara Teknik Sampling secara Sistematis (Systematic sampling). Sampel menggunakan angka kelipatan 5 untuk menentukan jumlah sampel. Maka nomor yang dipilih adalah populasi yang memiliki nomor $5,10,15, \ldots . .$. dst.

Tabel 2:

Nomor Urut dalam Teknik Sampling Probabilitas Secara Systematic Sampling

\begin{tabular}{|c|c|c|c|c|c|c|c|c|c|}
\hline 5 & 10 & 15 & 20 & 25 & 30 & 35 & 40 & 45 & 50 \\
\hline 55 & 60 & 65 & 70 & 75 & 80 & 85 & 90 & 95 & 100 \\
\hline 105 & 110 & 115 & 120 & 125 & 130 & 135 & 140 & 145 & 150 \\
\hline 155 & 160 & 165 & 170 & 175 & 180 & 185 & 190 & 195 & 200 \\
\hline 205 & 210 & 215 & 220 & 225 & 230 & 235 & 240 & 245 & 250 \\
\hline 255 & 260 & 265 & 270 & 275 & & & & & \\
\hline
\end{tabular}

Jadi jumlah sampel dengan kelipatan 5 dari jumlah populasi 278 Usaha Kecil Menengah (UKM) adalah berjumlah 55 UKM.

\section{Jenis dan Sumber Data}

"Chairul Anwar, 2017:51" Pada penelitian kuantitatif, analisis data yang digunakan dalam penelitian ini menggunakan langkah-langkah sebagai berikut :

1. Editing : Pada penelitian ini, editing dilakukan untuk menguji kesesuian hipotesis $\mathrm{Ho}_{\mathrm{an}} \mathrm{H}_{1}-\mathrm{H}_{5}$ atas variabel independen (Cash Ratio, Current Ratio, Return On Asset (ROA), Return On Equity (ROE), dan Net Profit Margin (NPM)) berpengaruh atau tidak terhadap variabel dependen (Sistem Informasi Akuntansi).

2. Coding : Coding atau memberi kode pada data yang dilakukan dengan tujuan merubah data kualitatif menjadi data kuantitatif (kuantifikasi data) atau memebedakan aneka karakter.

3. Tabulasi data : Tabulasi data atau memasukan data kedalam tabel-tabel yang telah disediakan, baik tabel untuk data mentah maupun data kerja untuk menghitung data tertentu secara statistik.

Dalam penelitian ini sumber data yang digunakan oleh peneliti adalah :

1. Data Primer : Data primer adalah data yang didapat dari sumber pertama baik dari individu atau perorangan. Data primer dalam penelitian ini berupa hasil jawaban yang diperoleh dari wawancara pemilik Usaha Kecil Menengah (UKM) yang tersebar di Bandar Lampung.

2. Data Sekunder : Data sekunder merupakan data primer yang diolah lebih lanjut dan dikumpulkan dari sumber yang telah ada baik data internal maupun eksternal organisasai. Pada penelitian ini peneliti mendapatkan data yang telah ada berupa jumlah Usaha Kecil Menengah yang telah ada pada Kamar Dagang dan Industri (KADIN) dan atau Departemen 
Perdagangan dan Perindustrian (Deperindag) kota Bandar Lampung dan yang tercatat pada Badan Pusat Statistik (BPS) provinsi Lampung

\section{Teknik Pengumpulan Data}

1. Observasi : Pada penelitian ini, dilakukan observasi secara langsung untuk memperoleh data primer dengan cara melakukan survei langsung ke Usaha Kecil dan Menengah (UKM) dan mewawancarai pihak pengelola Usaha Kecil dan Menengah (UKM). Jenis observasi yang digunakan dalam penelitian ini yaitu Non Perticipant Observation dimana peneliti tidak ikut secara langsung dalam kegiatan atau proses yang diamati, peneliti hanya sebagai pengamat dan mencatat berbagai peristiwa yang dianggap perlu saja sebagai data penunjang dalam penelitiian.

2. Wawancara : Wawancara merupakan teknik pengumpulan data yang dilakukan melalui tatap muka dan tanya jawab langsung antara peneliti terhadap nara sumber atau sumber data. Dalam penelitian ini, peneliti secara langsung melakukan wawancara kepada pemilik Usaha Kecil dan Menengah di Bandar Lampung yang telah terpilih sebagai responden. Disini peneliti telah membuat daftar pertanyaan yang digunakan untuk menggali informasi, dimana pertanyaan hanya berfokus pada Laporan Keuangan sederhana yang digunakan oleh Pemilik Usaha Kecil Menengah (UKM) yang akan digunakan untuk menghitung rasio keuangan dan membuktikan hipotesis.

3. Studi Kepustakaan : Studi kepustakaan adalah kegiatan untuk menghimpun informasi yang relevan dengan topik atau masalah yang manjadi objek penelitian.

\section{Variabel Penelitian}

“Cahirul Anwar, 2017:22" Variabel adalah segala sesuatu yang akan menjadi objek pengamatan penelitian. Dimana fenomena dalam penelitian ini yaitu Sistem Informasi Akuntansi (SIA) (sebagai variabel dependen) pada Usaha Kecil Menengah (UKM) di Bandar Lampung. Disini peneliti menggunakan pengukuran Kinerja Keuangan Usaha Kecil Menengah (UKM) dengan menggunakan instrumen penelitian perhitungan atas Skala Rasio sebagai variabel Independennya.

1. Variabel Independen : "Sugiyono, 2009:3" Variable ini sering disebut sebagai variabel stimulus, input, predikator, dan antecedent. Dalam bahasa indonesia sering disebut sebagai Variabel Bebas. Variabel independen dalam penelitian ini adalah Cash Ratio, Current Ratio, Return On Asset (ROA), Return On Equity (ROE), dan Net Profit Margin (NPM).

2. Variabel Dependen : "Sugiyono, 2009:3" sering disebut sebagai variabel respon, output, kriteria, konsekuen. Dalam bahasa indonesia sering disebut sebagai Variabel Terikat. Dalam penelitiain ini variabel dependen menggunakan sistem pengkodean Dummy, dimana variabel skala nominal regresi terletak divariabel dependen atau nilai Y. Artinya satu subjek/sampel adalah masuk dalam satu katagori, tidak boleh dua katagori. 
Pada penelitian ini variabel Y dihitung dengan menggunakan kode sebagai berikut :

a. Untuk responden Usaha Kecil Menengah (UKM) yang menggunakan Sistem Infromasi Akuntansi diberi kode $=1$,

b. Untuk responden Usaha Kecil Menengah (UKM) yang tidak menggunakan Sistem Infromasi Akuntansi diberi kode $=0$

\section{Alat Analisis}

Alat analisis pada penelitian ini menggunakan SPSS 23 (Statistical Product and Service Solution) karena program ini memiliki kemampuan analisis statistic yang cukup baik.

\section{Uji Asumsi Klasik}

Uji asumsi klasik dalam penelitian ini digunakan untuk mengetahui hubungan antar variabel penelitian yang ada dalam model regresi. Pengujian yang digunakan adalah uji normalitas, uji multikoloniaritas, uji heterokedastisitas, dan uji autokolerasi.

a. Uji Normalitas

Uji normalitas adalah pengujian mengenai kenormalan distribusi data. Uji ini bertujuan menguji apakan model regresi, variabel penggangu atau residual memiliki distribusi normal. Cara yang digunakan untuk mendeteksi apakah residual terdistribusi normal atau tidak adalah analisis grafik histogram serta uji stastistik non-parametik yaitu One Sample Kolmogrov Test (1-Sample K-S).

b. Uji Multikolonieritas

"Ghozali, 2011" Uji multikolonieritas bertujuan untuk menguji apakah terdapat kolerasi antar variabel independen dalam model regresi. Model regresi yang baik seharusnya bebas dari multikolonieritas. Deteksi terhadap ada tidaknya multikolonieritas dengan melihat nilai tolerance dan variance inflationfactor (VIF).

c. Uji Heterokedastisitas

Uji ini bertujuan untuk menguji apakah dalam model regresi terjadi ketidaksamaan variance dari residual satu pengamatan ke pengamatan yang lain. Jika variance dari residual satu pengamatan ke pengamatan lain tetap, maka disebut homoskedatisistas dan jika berbeda disebut heteroskedasitas. Model regresi yang baik adalah yang homokedatisitas atau tidak terjadi heterokedatisistas. Untuk mendeteksi adanya heterokedatisistas.

d. Uji Autokolerasi

"Ghozali, 2011" Uji autokolerasi bertujuan untuk menguji apakah model regresi linier ada kolerasi antara kesalahan pengganggu pada periode t dengan kesalahan pengganggu pada periode t-1 (sebelumnya). Jika terjadi kolerasi, maka ada masalah autokolerasi.

2. Analis Regresi Berganda

Pengujian hipotesis yang dilakukan dalam penelitian ini adalah dengan menggunakan model regresi berganda. Model ini digunakan untuk menguji pengaruh dua atau lebih variabel idependennya dengan skala pengukuran 
rasio terhadap variabel dependennya dengan menggunakan variabel skala nominal (varabel dummy).

Koefisien Determinasi $\left(\mathrm{R}^{2}\right)$

Koefisien Determinasi $\left(\mathrm{R}^{2}\right)$ pada intinya mengukur seberapa jauh kemampuan model dalam menerangkan variasi variabel dependen. Nilai keofisien determinasi antara nol dan satu. Nilai yang mendekati satu berarti variabel-variabel independen memberikan hampir semua informasi yang dibutuhkan untuk memprediksi variabel dependen.

3. Uji Hipotesis

Untuk membuktikan hipotesis diterima atau ditolak dilakukan pengujian hipotesis, yeitu berdiri dari uji simultan (uji Fhitung) dan uji persial (uji t).

a. Uji F

Pengujian ini dilakukan untuk mengetahui pengaruh suatu variabel independen secara persial terhadap variasi variabel dependen. Pengambilan keputusan juga dapat dilakukan dengan membandingkan nilai Fhitung dan nilai Ftabel.kriteria pengambilan keputusannya, yaitu :

1) Jika Fhitung $>$ Ftabel maka Ha diterima atau nilai signifikasi $(\alpha)<0,05$.

2) Jika Fhitung $<$ Ftabel maka H0 diterima atau nilai signifikasi $(\alpha)>0,05$.

b. Uji t

"Ghazali, 2013:125" Uji regresi persial ada dasarnya menunjukan seberapa jauh pengaruh satu variabel penjelas atau independen secara individual dalam menerangkan variasi - variabel dependen.

1) Jika $t$ hitung $<t$ tabel maka variabel independen tidak berpengaruh terhadap variabel dependen.

2) Jika t hitung $>$ t tabel maka variabel independen berpengaruh terhadap variabel dependen.

Jika angka signifikan t tabel lebih kecil dari $(\alpha)$ 0,05 maka dapat dikatakan bahwa ada pengaruh yang kuat antara variabel independen dengan variabel dependen. 


\section{Hasil Dan Pembahasan \\ Uji Asumsi Klasik}

1. Uji Normalitas

Pengujian normalitas dalam penelitian ini yaitu probability plot dengan menggunakan SPSS 22 dan diperoleh hasil sebagai berikut :

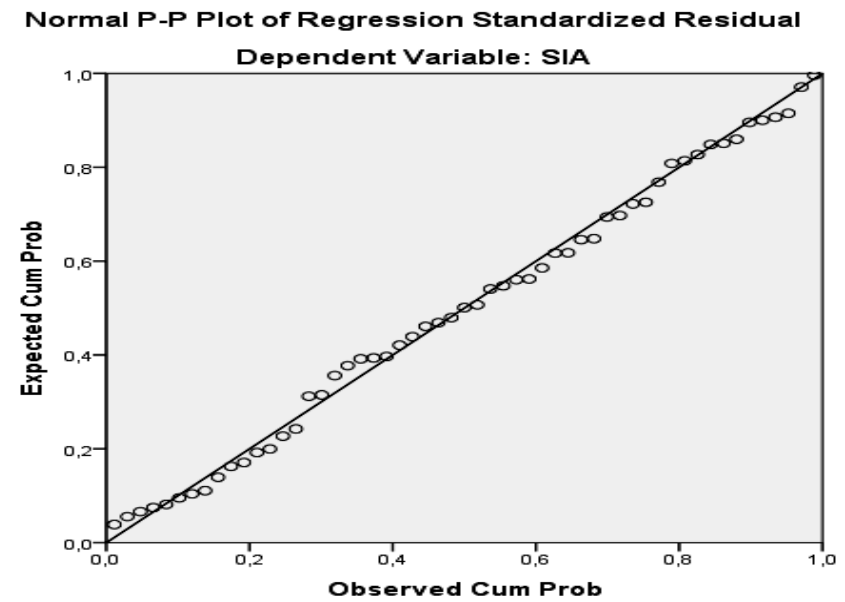

Sumber : Diolah Peneliti Gambar Uji Normalitas Dengan Normal Probability Plot

Berdasarkan gambar diatas dapat disimpulkan bahwa data dalam penelitian ini memenuhhi syarat probability plot sehingga model regresi dalam penelitia ini memenuhi asumsi normalitas yang artinya data dalam penelitian ini berasal dari populasi yang berdistribusi normal.

Uji normalitas juga dapat dilihat dari hasil one sampel kolmogorov test dengan menggunakan SPSS 22 dan diperoleh data sebagai berikut :

Tabel 3:

Hasil Uji Normalitas

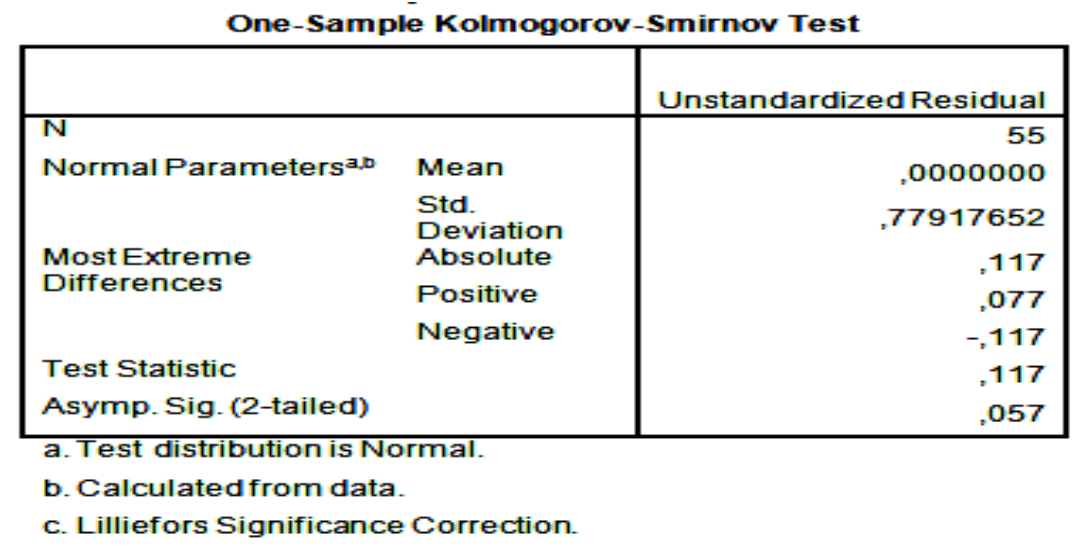

Berdasarkan tabel 2 diatas diketahui bahwa Asymp.sig lebib besar dari pada taraf signifikan yang telah ditetapkan $(0,57>0,05)$, maka dapat disimpulkan bahwa residual berdistribusi normal. 


\section{Uji Multikolonieritas}

Tabel 4:

Hasil Uji Multikolonieritas

\begin{tabular}{|c|c|c|c|c|c|c|c|}
\hline \multirow[b]{2}{*}{ Model } & \multicolumn{2}{|c|}{$\begin{array}{l}\text { Unstandardized } \\
\text { Coefficients }\end{array}$} & \multirow{2}{*}{$\begin{array}{c}\text { Standardized } \\
\text { Coefficients } \\
\text { Beta } \\
\end{array}$} & \multirow[b]{2}{*}{$t$} & \multirow[b]{2}{*}{ Sig. } & \multicolumn{2}{|c|}{$\begin{array}{l}\text { Collinearity } \\
\text { Statistics }\end{array}$} \\
\hline & $\mathrm{B}$ & $\begin{array}{l}\text { Std. } \\
\text { Error }\end{array}$ & & & & Toleranœ & VIF \\
\hline 1 (Constant) & 27,650 & 6,540 & & 4,228 & 000 & & \\
\hline CASHRATIO &,- 144 &, 045 & ,374 & $-3,182$ &, 003 & 898 & 1,114 \\
\hline $\begin{array}{l}\text { CURRENT } \\
\text { RATIO }\end{array}$ & 2,195 & 268 & 699 & 8,189 &, 000 & 824 & 1,214 \\
\hline ROA & 009 & ,104 & ,007 & ,083 & ,934 & 862 & 1,160 \\
\hline ROE & ,163 & ,073 & 195 & 2,242 &, 029 & ,793 & 1,261 \\
\hline NPM & .229 &, 106 & , 168 & 2,161 & 036 & ,996 & 1,004 \\
\hline
\end{tabular}

Dari tabel diatas dapat diketahui bahwa nilai tolerance unttuk semua variabel independen (Cash Ratio, Current Ratio, ROA, ROE,dan NPM) lebih besar dari 0,05 dan nilai VIF untuk semua variabel lebih keecil dari 10. Dengan demikian dapat disimpulkan bahwa tidak terjadi gejala multikolonieritas.

\section{Uji Heterokedastisitas}

Uji heterokedastisitas dilakukan dengan melihat grafik plot nilai prediksi variabel terikat (ZPRED) dengan residualnya (SRESID).

\section{Scatterplot}

Dependent Variable: SIA

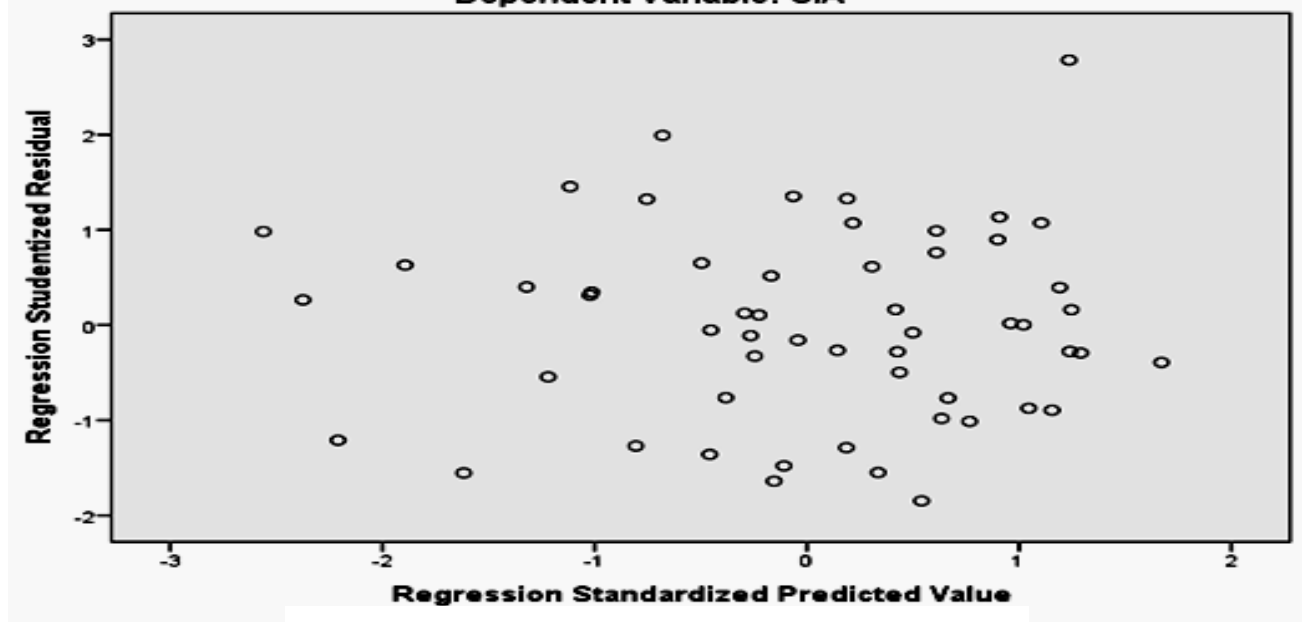

Sumber: Diolah Penulis

Dari gambar diatas dapat dilihat tidak ada pola tertentu serta titik-titik menyebar di atas dan di bawah sumbu Y angka nol pada sumbu Y, sehingga dapat diartikan bahwa tidak terjadi heterokedastisitas.

\section{Uji Autokolerasi}

Untuk mengetahui adanya autokelerasi digunakan uji Durbin-Watson, Berikut ini hasil uji Durbin-W atson dengan menggunakan program SPSS 22 : 
Tabel 5:

Hasil Uji Autokolerasi dengan Durbin Watson

\begin{tabular}{l|r|r|r|r|r|}
\hline Model & R & R Square & $\begin{array}{c}\text { Adjusted R } \\
\text { Square }\end{array}$ & $\begin{array}{c}\text { Std. Error of the } \\
\text { Estimate }\end{array}$ & $\begin{array}{c}\text { Durbin- } \\
\text { Watson }\end{array}$ \\
\hline 1 &, $840^{3}$ &, 705 &, 675 &, 274 & 1,862 \\
\hline
\end{tabular}
a.Predictors: (Constant), NPM, ROA, CURRENT RATIO, CASH RATIO, ROE
b. Dependent Variable: SIA

Sumber: Diolah Penulis

Hasil uji autokolerasi pada tabel diatas menunjukan nilai statistik DurbinWatson (D-W) sebesar 1.862. Nilai tersebut akan dibandingkan dengan batas atas DU dan batas bawah DL menggunakan nilai signifikan 5\% dengan jumlah sampel 55 dan jumlah variabel independen $5(K=5)$ pada tabel DurbinWatson (D-W), maka didapat nilai batas atas (DU) 1.7681 dan nilai batas bawah (DL) 1.3743. oleh karena itu, jika nilai DW lebih tinggi dari pada batas bawah atau Durbin Lower (DL) $(1,862>1.7681)$, maka dapat disimpulkan bahwa tidak terjadi gejala autokolerasi pada model regresi.

Berdasarkan hasil dari uji asumsi klasik (normalitas, multikolonieritas, heterokedastiditas, dan autokolerasi) pada penelitian ini diperoleh bahwa dalam model yang digunakan sudah tidak terjadi penyimpangan asumsi klasik, artrinya model regresi pada penelitian ini dapat digunakan sebagai dasar analisis.

\section{Analisis Regresi Linier Berganda}

Hasil analisis disajikan pada tabel berikut ini :

Tabel 6:

Analisis Regresi

\begin{tabular}{|c|c|c|c|c|c|}
\hline \multicolumn{6}{|c|}{ Coefficients $^{a}$} \\
\hline \multirow[b]{2}{*}{ Model } & \multicolumn{2}{|c|}{ Unstandardized Coefficients } & \multirow{2}{*}{$\begin{array}{c}\begin{array}{c}\text { Standardized } \\
\text { Coefficients }\end{array} \\
\text { Beta }\end{array}$} & \multirow[b]{2}{*}{$\mathrm{t}$} & \multirow[b]{2}{*}{ Sig. } \\
\hline & $\mathrm{B}$ & Std. Error & & & \\
\hline 1 (Constant) & 27,650 & 6,540 & & 4,228 &, 000 \\
\hline CASHRATIO &,- 144 & 045 &,- 374 & $-3,182$ &, 003 \\
\hline $\begin{array}{l}\text { CURRENT } \\
\text { RATIO }\end{array}$ & 2,195 & 268 & 699 & 8,189 &, 000 \\
\hline ROA & 009 & ,104 &, 007 & 083 &, 934 \\
\hline ROE & 163 & 073 & 195 & 2,242 &, 029 \\
\hline NPM &, 229 & 106 & 168 & 2,161 &, 036 \\
\hline
\end{tabular}

Sumber: Diolah Penulis

Berdasarkan tabel diatas dapat diperoleh persamaan sebagai berikut :

SIA = 27,650 - 144 Cash Ratio + 2,195 Current Ratio + 0,009 ROA + 0,163 ROE + 0,229 NPM +e 


\section{Koefisien Determinasi $\left(\mathbf{R}^{2}\right)$}

Berikut adalah hasil uji koefisien determinasi :

Tabel 7:

Model Summary ${ }^{b}$

\begin{tabular}{|l|r|r|r|r|}
\hline Model & $\mathrm{R}$ & R Square & $\begin{array}{l}\text { Adjusted } \\
\text { R Square }\end{array}$ & $\begin{array}{l}\text { Std. Error of } \\
\text { the Estimate }\end{array}$ \\
\hline 1 &, $840^{\mathrm{a}}$ &, 705 &, 675 &, 274 \\
\hline
\end{tabular}

:s: (Constant), NPM, ROA, CURRENT RATIO, CASH

JE

b. Dependent Variable: SIA

Berdasarkan tabel diatas dapat diketahui nilai $\mathrm{R}$ Square sebesar 0,705 atau 70,50\% maka SIA (Y) dapat dijelaskan oleh Cash Ratio, Current Ratio, ROA, ROE, dan NPM (X1, X2, X3, X4, dan X5) sebesar 70,50\%, dan sisanya sebesar 29,50\% dijelaskan oleh faktor lain diluar penelitian.

\section{Uji Hipotesis}

Untuk membuktikan uji hipotesis, yaitu terdiri dari uji simultan (uji F) dan uji persial (uji t).

\section{Uji F}

Untuk keperluan analisis signifikasi model regresi yang diajukan, maka disajikan dalam tabel berikut :

Tabel 8:

ANOVA $^{a}$

\begin{tabular}{|c|c|c|c|c|c|}
\hline Model & $\begin{array}{l}\text { Sum of } \\
\text { Squares }\end{array}$ & Df & Mean Square & $\mathrm{F}$ & Sig. \\
\hline 1 Regression & 16,961 & 5 & \multirow{3}{*}{$\begin{array}{r}3,392 \\
, 669\end{array}$} & \multirow[t]{3}{*}{5,070} & \multirow[t]{3}{*}{, $001^{\mathrm{b}}$} \\
\hline Residual & 32,784 & 49 & & & \\
\hline Total & 49,745 & 54 & & & \\
\hline
\end{tabular}

a. Dependent Variable: SIA

b. Predictors: (Constant), NPM, CASH RATIO, CURRENT RATIO, ROE, ROA

Tabel diatas menunjukan nilai sig $0.001<0.005$, maka hipotesis ke 6 (H6) yang berbunyi "rasio Cash Ratio, Current Ratio, Return On Asset, Return On Equity, dan Net Profit Margin berpengaruh secara bersama-sama terhadap Sistem Informasi Akuntansi (SIA) pada Usaha Kecil Menengah di Bandar Lampung diterima, $\mathrm{H} 0$ ditolak.

\section{Uji Signifikansi t}

Uji ini dilakukan dengan membandingkan t hitung dengan t tabel. Pada penelitian ini, variabel yang diteliti berjumlah 5 (Cash Ratio, Current Ratio, Return On Asset, Return On Equity, dan Net Profit Margin) dan sampel berjumlah 55 UKM. Dengan menggunakan taraf signifikansi sebesar $5 \%$ atau 0.05 . dari perhitungan yang diperoleh maka dapat dilihat nilai $t$ tabel pada tabel presentase distribusi $t$ didapatkan nilai $t$ tabel sebesar 2,00856. 
Tabel 9:

Hasil Uji t

\begin{tabular}{|c|c|c|c|c|c|}
\hline & & Coefficients & & & \\
\hline \multirow[b]{2}{*}{ Model } & \multicolumn{2}{|c|}{ Unstandardized Coefficients } & \multirow{2}{*}{$\begin{array}{c}\text { Standardized } \\
\text { Coefficients } \\
\text { Beta }\end{array}$} & \multirow[b]{2}{*}{$t$} & \multirow[b]{2}{*}{ Sig. } \\
\hline & $\mathrm{B}$ & Std. Error & & & \\
\hline 1 (Constant) & 27,650 & 6,540 & & 4,228 & .000 \\
\hline CASHRATIO &,- 144 & 045 &,- 374 & $-3,182$ &, 003 \\
\hline $\begin{array}{l}\text { CURRENT } \\
\text { RATIO }\end{array}$ & 2,195 & 268 & 699 & 8,189 &, 000 \\
\hline ROA & 009 & 104 & 007 & 083 & 934 \\
\hline ROE & , 163 & 073 & 195 & 2,242 & 029 \\
\hline NPM & ,229 & 106 & ,168 & 2,161 & 036 \\
\hline
\end{tabular}

Sumber: Diolah Penulis

\section{Kesimpulan}

Berdasarkan hasil penelitian secara keseluruhan dapat diambil kesimpulan sebagai berikut :

1. Kinerja keuangan Cash Ratio secara persial berpengaruh terhadap Sistem Informasi Akuntansi (SIA) pada UKM di Bandar Lampung. Rata-rata industri untuk cash ratio adalah 50\% maka keadaan perusahaan lebih baik dari perusahaan lain bila berada diantara rata-rata industri. Namun, kondisi ratio kas terlalu tinggi juga kurang baik karena ada dana yang menganggur atau yang tidak atau belum digunakan secara optimal.

2. Kinerja keuangan Current Ratio secara persial berpengaruh terhadap Sistem Informasi Akuntansi (SIA) pada UKM di Bandar Lampung. apabila ratio lancar rendah dapat dikatakan bahwa perusahaan kurang modal untuk membayar utang. Hal ini dapat saja terjadi karena kas tidak digunakan sebaik mungkin.

3. Kinerja keuangan Return On Asset secara persial tidak berpengaruh terhadap Sistem Informasi Akuntansi (SIA) pada UKM di Bandar Lampung. Semakin tinggi angka Return On Asset (ROA) yang diperoleh, maka semakin tinggi tingkat pengembalian terhadap asset yang telah dihasilkan oleh perusahaan, rasio ini digunakan pada penelitian ini.

4. Kinerja keuangan Return On Equity secara persial berpengaruh terhadap Sistem Informasi Akuntansi (SIA) pada UKM di Bandar Lampung. Rasio ini juga mencerminkan kemampuan ekuitas perusahaan dalam menghasilkan laba.

5. Kinerja keuangan Return On Equity secara persial berpengaruh terhadap Sistem Informasi Akuntansi (SIA) pada UKM di Bandar Lampung. Semakin tinggi Net Profit Margin semakin baik operasi perusahaan, rasio ini mengukur hasil akhir dari kegiatan dari operasi perusahaan.

6. Kinerja keuangan Cash Ratio, Current Ratio, Return On Asset, Return On Equity, dan Net Profit Margin secara bersama-sama terhadap Sistem Informasi Akuntansi (SIA) pada UKM di Bandar Lampung. Perubahan yang terjadi pada sistem informasi akuntansi (SIA) (Y) dapat dijelaskan oleh variabel Cash Ratio, Current Ratio, ROA, ROE, dan NPM sebesar 
$70,50 \%$, dan sisanya sebesar 29,50\% dijelaskan oleh variabel lain yang tidak diajukan dalam penelitian ini.

\section{Referensi}

Anugrah Mandiri, CV.Panji (2017). Profil Industri Mikro dan Kecil, Bandar Lampung : BPS RI/BPS-Statistics Indonesia.

Anwar, Chairul (2017). Metodologi Penelitian. Bandar Lampung

Buku Panduan Skripsi STIE Mitra Lampung 2017

CPS.Soft, Cipta Prianti Sejabtera (2018). Peran Akuntansi Dalam Perkembangan UKM di Indonesia. 18 Oktober 2018. Copyright@2019

Hadi, Purnomo (2016). Pengembangan Usaha Mikro, Kecil Dan Menengah (UMKM). Bogor : Catur HP Terbitan: GagasMedia

Tamila Ponti, Hanna. 2012. Analisis Eksistensi Sistem Informasi Akuntansi (SIA) dengan Kinerja Keuangan Pada Usaha Kecil dan Menengah (UKM) di Bandar Lampung. Fakultas Ekonomi Jurusan Akuntansi Universitas Malahayati : Bandar Lampung.

Ghozali, Imam. (2011). Aplikasi Analisis Multivariate Dengan Program SPSS. Semarang: Badan Penerbit Universitas Diponegoro. Gumanti, T. A. dan N. Alkaf.

KajianPustaka.com, (2017). Return On Asset (ROA). 06 Agustus 2017. https://www.kajianpustaka.com/2017/08/return-on-assets-roa.html.

Kasmir. (2014). Analisis Laporan Keuangan, Edisi kesatu, cetakan kedelapan. Jakarta: PT. Raja Grafindo Persada.

Kompas.Com. (2018). Masih Banyak Pelaku UMKM "Buta" Akuntansi, 30 Agustus 2018. www.kompas.com.

Mardi. (2014). Sistem Informasi Akuntansi Cet. 2. Bogor : Ghalia Indonesia.

Nainggolan, Pahala. (2015). Hitung Untung Bisnis UKM untuk Bisnis Kecil dan Menengah. Jakarta : Penerbit PPM

Prastika Esti, Nurhikmah. (2018). Pengaruh Sistem Informasi Akuntansi Terhadap Kinerja Keuangan Perusahaan Pada Usaha Mikro Kecil Dan Menengah (Umkm) Di Kota Pekalongan. (Jurnal LITBANG: 2019 jurnal.pekalongankota.go. id)

Romney, Marshall.B, dan Paul John Steinbart. (2015). Accounting Information System. Edisi 13, alihbahasa: Kikin Sakinah Nur Safira dan Novita Puspasari, Jakarta: Salemba Empat. 
Pengaruh Kinerja Keuangan terhadap Sistem .... 